\title{
RESTRUKTURISASI ORGANISASI DAKWAH YANG KOMPREHENSIP [Kajian Terhadap Upaya Penjabaran Dakwah Berdasarkan PMA No. 13 Tahun 2012]
}

\author{
Kholili \\ Fakultas Dakwah dan Komunikasi \\ UIN Sunan Kalijaga Yogyakarta \\ e-mail: hmkholili@yahoo.com
}

\begin{abstract}
Islamic Information Directorate in charge of da'wah Islam, the structure and the task would be a lot of contact with the activities of information da'wah and extension da'wah. But officials in the field of da'wah is unclear, as the structure and tasks should be done. The research problem: How to design the da'wah of Islam in the PMA 13-2012. How policy makers formulate information da'wah and extension da'wah at all levels of the ministry of religion. Objective: Assess the design of the da'wah of Islam in the PMA 13 2012 and analyze how the policy makers to formulate information da'wah and extension da'wah. Research Methods. The study uses a case study to examine many documents that seeks to provide a detailed overview of the PMA 13 - 2012, but some things carefully studied and confirmed to officials associated with FGDs and in-depth interviews. There are many programs, righ now are revolve around administration technical issues, not much goes to the development of da'wah materials and methods strategically. Da'wah program, righ now, there is a program is to overcome problems that appear in society, not to get in to the undertakings of the design strategy for long-term da'wah.
\end{abstract}

\section{Key Words:}

Wisdom Da'wah, Organization, Information, Extension 


\section{Abstrak}

Direktorat Informasi Islam yang membawahi dakwah Islam, struktur dan tugasnya akan banyak berhubungan dengan kegiatan dakwah dan ekstensi dakwah. Tapi pejabat di bidang dakwah tidak jelas, karena struktur dan tugasnya harus dilakukan. Masalah penelitian: Bagaimana merancang dakwah Islam di PMA 13- 2012. Bagaimana pembuat kebijakan merumuskan dakwah dan ekstensi dakwah di semua tingkat kementerian agama. Tujuan: Menilai disain dakwah Islam di PMA 13 - 2012 dan menganalisa bagaimana pembuat kebijakan merumuskan dakwah dan ekstensi dakwah. Metode penelitian. Studi ini menggunakan studi kasus untuk memeriksa banyak dokumen yang berusaha memberikan gambaran rinci tentang PMA 13 - 2012, namun beberapa hal dipelajari dan dikonfirmasikan dengan hati-hati kepada petugas yang terkait dengan FGD dan wawancara mendalam. Ada banyak program, sekarang sudah banyak membahas masalah teknis administrasi, tidak banyak yang membahas pengembangan materi dakwah dan metode secara strategis. Program dakwah, baik sekarang, ada sebuah program untuk mengatasi permasalahan yang muncul di masyarakat, tidak sampai pada usaha strategi perancangan dakwah jangka panjang.

\section{Kata Kunci:}

Kebijaksanaan Da'wah, Organisasi, Informasi, Exktensi 


\section{A. Pendahuluan}

Melihat sisi organisasi, Kementerian Agama RI secara struktural, berdasarkan PMA No. 13 Tahun 2012 tentang Organisasi dan Tata Kerja Instansi Vertikal Kementerian Agama. Struktur yang ada untuk mengembangkan dan melaksanakan dakwah bil hikmah yang meliputi dakwah penerangan (mujadalah ahsan) dan dakwah penyuluhan (mujadalah ahsan), tidaklah linier sehingga struktur organisasi tersebut tidak cukup mendukung untuk menjadikan dakwah yang dilakukan berhasil maksimal. Struktur organisasiyang ada seharusnya mendukung untuk melakukan kegiatan-kegiatan dakwah penerangan dan dakwah penyuluhan secara proporsinal, komprehensip dan berkesinambungan. Sementara selama ini, dakwah penyuluhan banyak menggunakan metode penerangan, sedangkan kegiatan dakwah penerangan tidak maksimal dilakukan dan tidak dilanjutkan dengan dakwah penyuluhan. Rumusan masalah: 1) Bagaimana Konstruksi Dakwah Islam yang Tertuang dalam PMA 13- 2012; 2); Bagaimana Pengambil Kebijakan Merumuskan Progrm Penerangan Agama dan Penyuluhan Agama di masing-masing Tingkat Kementerian Agama.

\section{B. Konsep Dakwah Islam}

Dakwah Islam merupakan suatu seruan kepada ajaran Islam dengan cara-cara yang baik, sebgaimana firman Allah SWT dalam Qs. An-Nahl (16): 125 yang artinya, "Serulah (manusia) kepada jalan Tuhanmu dengan hikmah dan pelajaran yang baik dan bantahlah mereka dengan cara yang baik ${ }^{39}$....Wahai Rabb-ku, berilah aku hikmah, dan masukkanlah aku ke dalam golongan orang-orang yang shaleh." 40 Berdasarkan analisis Qohthani, ${ }^{41}$ hikmah itu ada dua. Bagian kalimat 'berilah aku hikmah' dalam ayat di atas merupakan hikmah teoretis, yaitu

\footnotetext{
${ }^{39}$ Q.S. An-Nahl [16]: 125.

${ }^{40}$ Q.S. Asy syu'ara [26]: 83.

${ }^{41}$ Said bin Ali Qahthani, Dakwah Islam Dakwah Bijak, teri. Masykur Hakim (Jakarta: Gema Insani Press, 1994), 27.
} 
mavidhah hasanah yang dalam perspektif komunikasi dikenal dengan komunikasi penerangan; sedangkan bagian kalimat'dan masukkanlah aku ke dalam golongan orang-orang shaleh' merupakan hikmah praktis, yaitu mujadalah ahsan yang dalam perspektif komunikasi dikenal dengan komunikasi penyuluhan. ${ }^{42}$

\section{Gambar 1}

Metode Dakwah Berdasar Konsep Hikmah dari Qohthanii3

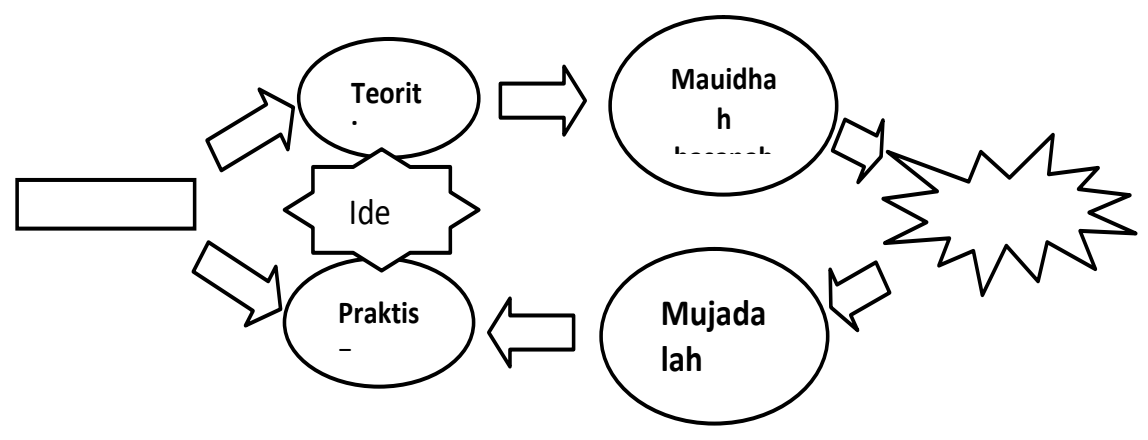

Mavidhah Hasanah dengan Komunikasi Penerangan dan Mujadalah Ahsan dengan Komunikasi Penyuluhan. Mavidhah hasanah lebih bisa dikatakan sebagai metode dakwah dengan kategori tabligh, yang mempunyai arti menyampaikan, menyampaikan apa yang diturunkan Allah. ${ }^{44}$ Komunikatornya disebut "muballigh". Dakwah dengan tabligh berarti menyampaikan ajaran Islam kepada orang lain yang lebih bersifat pengenalan dasar tentang Islam. ${ }^{45}$ Kegiatan dakwah pada tahap awal adalah dakwah yang sekedar menyampaikan untuk bisa dipahami, ${ }^{46}$ karena tugas para nabi dan pendakwah pada umumnya

${ }^{42} \mathrm{HM}$. Kholili, Syamsul Hadi dan Subejo, Islam yang Rahmat dalam Membangun Umat, dalam Jurnal Kawistara, Vol. 4, No. 3 Desember (Yogyakarta: SPS UGM, 2014), 300.

${ }^{43} \mathrm{HM}$. Kholili, Dakwah Penyuluh Agama Islam Fungsional (PAIF) Bimas Islam dalam Membangun Umat di Kabupaten Sleman (Disertasi- Universitas Gajah Mada, 2015), 43

${ }^{44}$ Q.S. al-Maidah [5]: 67.

${ }^{45}$ M. Ali Aziz, Ilmu Dakwah, Edisi Revisi (Jakarta: Kencana Prenada Group, 2009), 20.

${ }^{46}$ Q.S. Ya $\sin [36]: 17$. 
hanyalah tabligh (menyampaikan) pada umatnya. ${ }^{47}$ Oleh karena itu kegiatan tabligh dilaksanakan pada tahap awal dakwah.

Ketika dawah dilakukan satu arah dalam bentuk tabligh, dakwah penerangan, permasalahannya adalah suatu saat, dimungkinkan ada jama'ah sasaran dakwah yang mengalami kesulitan dalam melaksanakan pesan dakwah yang diterimannya, dan ada kecenderungan untuk menolaknya karena suatu hal, misalnya karena tidak bisa atau tidak biasa mereka lakukan. Menghadapi kondisi tersebut, tentulah diperlukan penjelasan lebih lanjut dalam sebuah dialog terkait apa yang masih menjadi masalah dengan pesan yang diterimanya itu. Di sinilah diperlukan dakwah mujadalah atau dialog pada tahap berikutnya dalam mana kegiatan dakwah ini kemudian dikenal dengan penyuluhan agama yang pelaksanaannya akan banyak dikembangkan dengan komunikasi penyuluhan.

Dalam kajian ilmu komunikasi, sebuah proses komunikasi dalam mana komunikator hanya berfungsi sebagai penyampai informasi saja, komunikasi hanya bersifattop down darikomunikatorkepada komunikan dengan tanpa adanya timbal balik dari komunikan. Komunikasi yang demikian ini dikategorikan komunikasi penerangan. ${ }^{48}$

Penyuluhan perlu dibedakan dengan penerangan. Penerangan "hanya" merupakan upaya menyampaikan pesan kepada masyarakat supaya menjadi tahu dan sadar akan adanya sesuatu. Dalam prakteknya, "penerangan" dapat merupakan tahap awal penyuluhan. Penyuluhan mempunyai tujuan lebih jauh, yaitu sampai dengan menimbulkan hasrat atau keinginan dari penerima pesan (sasaran) penyuluhan yang dengan kesadarannya sendiri tanpa paksaan melakukan penilaian sehingga tumbuh keyakinan kemudian

${ }^{47}$ Aziz, Ilmu ..., 22.

${ }^{48}$ Erik Zulfikar, unixlifes. blogspot.com/201 1/10/ilmu-penerangan.html, diakses tanggal 12-7-2013. 
mencoba dan selanjutnya menerapkan pesan atau informasi dan atau pengetahuan yang diterimanya. ${ }^{49}$

Memang, komunikasi penerangan yang banyak menggunakan media siaran seperti radio dan televisi, orientasinya cenderung kuat satu arah, ${ }^{50}$ mengkategorikan komunikasi tersebut berfungsi sebagai bentuk legitimizer progrm-program pembangunan dalam mana komunikasi dapat memusatkan perhatian audiensnya kepada program-program tersebut dan menimbulkan suatu suasana kebenaran, sehingga dapat menggalang dukungan sosial bagi pelaksanaan program-program yang dicanangkan. ${ }^{51}$

Pada dasarnya penyuluhan merupakan proses komunikasi. Ketika pengertian penyuluhan sebagai proses perubahan perilaku, ${ }^{52}$ maka komunikasi penyuluhan bukan komunikasi yang sekedar memberitahu atau menerangkan tentang pesan apa yang disampaikan. Komunikasi penyuluhan sebuah proses komunikasi timbal balik antara komunikator dan komunikan yang berusaha merubah perilaku (pengetahuan, sikap dan keterampilan) masyarakat sasarannya, agar mereka tahu, mau dan mampu melaksanakan perubahan-perubahan dalam usahanya untuk mencapai perbaikan dan peningkatan hidup dan kehidupan termasuk diantaranya kesejahteraan keluarga atau masyarakatnya.

Penelitian menggunakan studi kasus untuk memberikan gambaran secara mendetail yang khas dari kasus. ${ }^{53}$ Penelitian lebih banyak pada telaah data dokumen, namun beberapa hal dilakukan pendalaman

\footnotetext{
${ }^{49}$ Subejo, Bahan Kuliah Dasar-dasar Penyuluhan dan Komunikasi Pertanian, (Yogyakarta: Fakultas Pertanian UGM, 2012).

${ }^{50}$ Amri Jahi, "Media Siaran dalam Pembangunn Pedesaan di Negara-negara Dunia Ketiga", dalam Amri Jahi (ed.), Komunikasi Massa dan Pembangunan Pedesaan di Negaranegara Dunia Ketiga, (Jakarta: Gramedia Pustaka Utama, 1993), 126-131.

51Jahi..., "Media ..., 126-129.

${ }^{52}$ Totok Mardikanto, Penyuluhan Pembangunan Pertanian (Surakarta: Sebelas Maret Univercity Press, 1993), 13-14.

${ }^{53}$ M. Nazir, Metode Peneelitian (Jakarta: Ghalia Indonsia, 1985), 66
} 
dengan Focus Group Discussion (FGD), ${ }^{54}$ yaitu dengan diskusi kelompok terarah dan melakukan konfirmasi kepada sumber terkait dengan wawancara. ${ }^{55}$

\section{Hasil Penelitian dan Rekomendasi}

Kementerian Agama sebagai institusi pemerintah yang menangani bidang keagamaan masyarakat memang sudah memiliki unit organisasi yang membidangi pengelolaan dakwah. Namun, nama unit organisasi tersebut dalam struktur yang ada belum konsisten dan berubah-ubah dan belum linier. Struktur Organisasi yang menangani Bidang Dakwah di Kementerian Agama Pusat bernama Direktorat Penerangan Agama Islam yang berada di bawah Ditjen Bimas Islam; ${ }^{56}$ di Kantor Wilayah Kementerian Agama, sebagai contoh untuk Provinsi Daerah Istimewa Yogyakarta berada pada Bidang Penerangan Agama Islam, Zakat, dan Wakaf. ${ }^{57}$ Sedangkan di Kantor Kementerian Agama Kabupaten/Kota, penyelenggaraan bidang dakwah berada pada Seksi Bimbingan Masyarakat Islam. ${ }^{58}$

${ }^{54} \mathrm{C}$. Anyaegbunam, P. Mefalopulos dan T. Moetsabi., Participatory Rural Communication Appraisal, Starting With The People A Handbook, Second Edition (Rome: FAO, 2004), 68.

${ }^{55}$ N. K. Ratna, Metodologi Penelitian, Kajian Budaya dan Ilmu Sosial Humaniora pada Umumnya (Yogyakarta: Pustaka Pelajar, 2010), 221-222.

${ }^{56} \mathrm{http}$ ://bimasislam.kemenag.go.id/profil/struktur-organisasi.html, tanggal 22-112013.

57PMA No. 13 T 2012 Pasal 432, ayat 1.

58PMA No. 13 T 2012: Pasal 461, ayat 1,2,3. 
Gambar 2

\section{Posisi Dakwah dalam Struktur Kemenag Pusat ${ }^{59}$}

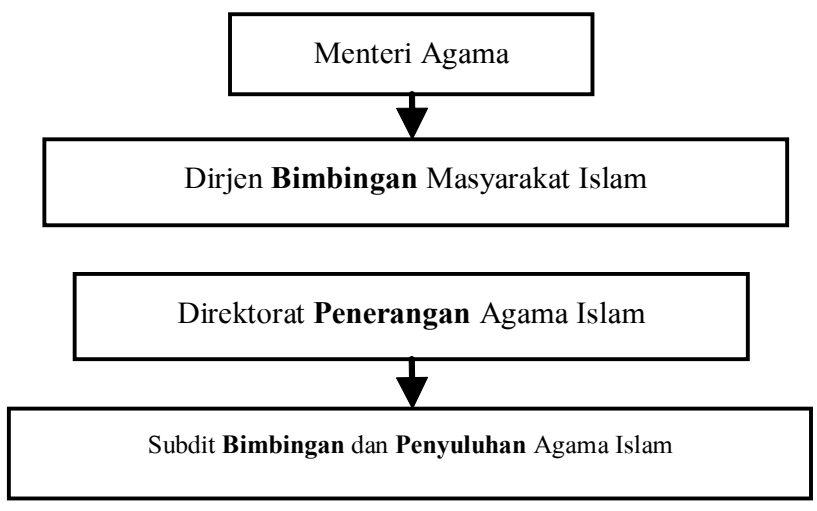

Berdasarkan PMA No. 13 Th. 2012, ada nama struktur yang berubah-ubah dan tidak linier seperti nama struktur "Bimbingan""Penerangan"- "Penyuluhan"- "Publikasi". Di Kemenag Pusat ada "Dirjen Bimbingan Masyarakat"; di bawahnya ada "Direktorat Penerangan Agama Islam"; di bawahnya lagi ada "Subdit Bimbingan dan Penyuluhan Agama Islam".

\section{Gambar 3}

Struktur Kedakwahan Kanwil Kemenag Provinsi ${ }^{60}$

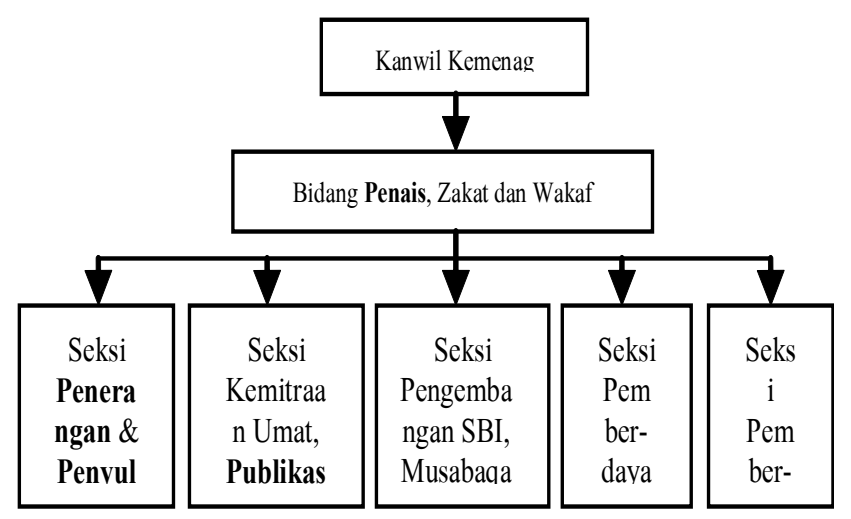

\footnotetext{
${ }^{59}$ Diolah berdasarkan PMA No. 13 T 2012.

${ }^{60}$ Diolah berdasarkan PMA No. 13 T 2012.
} 
Pada struktur di bawah Kanwil ada "Bidang Penais, Zakat dan Wakaf"; struktur di bawahnya ada "Seksi Penerangan dan Penyuluhan Agama Islam", "Seksi Kemitraan Umat, Publikasi Dakwah, dan Hari Besar Islam", "Seksi Pengembangan Seni Budaya Islam, Musabaqah Al-Qur'an al-Hadits", Seksi Pemberdayaan Zakat" dan "Seksi Pemberdayaan Wakaf"

Ketika di bawah Bidang Penais (Penerangan Agama Islam) ada Seksi Penerangan \& Penyuluhan Agama Islam, struktur ini memperlihatkan bahwa, apakah Penais meliputi Penerangan \& Penyuluhan Agama Islam. Ada perbedaan antara "penerangan"yang ada di Bidang Penais dengan "penerangan" yang ada di Seksi Penerangan \& Penyuluhan Agama Islam. Posisi "Seksi Kemitraan Umat, Publikasi Dkwah dan $\mathrm{HBI}$ " yang terpisah dengan "seksi Penerangan dan Penyuluhan Agama Islam" dalam sebuah struktur. Pada hal seksi publikasi menjadi bagian atau penunjang bagi dakwah penerangan. Artinya, mengapa di Kanwil Kementerian Agama ada Seksi Penerangan Agama Islam dan Seksi Publikasi Dakwah berada dalam struktur yang berbeda/terpisah, sementara kegiatan-kegiatan pada kedua seksi itu merupakan satu kesatuan. Sedangkan di Kemenag Pusat Subdit Publikasi Dakwah dan Hari Besar Islam menidi satu bagian dari Direktorat Penerangan Islam. Masalah ini juga perlu pencermatan, penyusunan konsep dan penataan kembali antara dakwah penerangan dan dakwah penyuluhan.

Dalam hal program dakwah, berdasarkan data yang diperoleh di lapangan memperlihatkan bahwa: 1). Program dakwah yang ada belum memproporsikan dakwah penerangan dan dakwah penyuluhan; 2). Program yang ada baru banyak berkisar pada masalah tehnis administrsi, belum banyak masuk kepada pengembangan materi dan metode dakwah yang strategis; 3). Program dakwah yang ada baru bersifat mengatasi masalah yang mucul di mayarakat, belum masuk kepada vapaya perancangan strategi dakwah untuk jangka panjang. 
Coba kita mencermati Visi Kementerian Agama yang berbunyi: "Terwujudnya masyarakat Indonesia yang taat beragama, rukun, cerdas, mandiri, dan sejahtera lahir batin." Jika visi-misi ini dijadikan dasar oleh Dirjen Bimas Islam untuk melangkah di bidang dakwah maka "Kegiatan rencana program bimbingan masyarakat Islam 2010-2014 serta rencana kerja dan anggaran tingkat Pusat dan Daerah" yang dilakukan, tidak banyak membantu mewujudkan visimisi dari kegiatan itu sendiri. Hal tersebut terjadi karena "Isu-isu Strategis" Bidang Penerangan Agama Islam yang dibahas dan "Materi Sidang Komisi" dalam pertemuan itu tidak sepenuhnya menunjang bagaiamana terwujudnya visi-misi yang dicanangkan. Materi sidang dan isu-isu strategis yang dibahas lebih pada upaya penguatan kelembagaan dakwah yang lembaga ini banyak di luar kendali kementerian, sementara fokus dari isu-isu strategis dan materi sidang komisi lebih kepada upaya penyelesaian masalah yang muncul, misalnya radikalisme; sementara bagaimana umat menjadi taat beragama, maju, sejahtera, cerdas tidaklah banyak dibahas.

Tabel 1

Output Program dan Kegiatan Pengelolaan dan Pembinaan Kualitas Penerangan Agama Islam ${ }^{61}$

\begin{tabular}{|c|l|l|}
\hline No. & \multicolumn{1}{|c|}{ Ranah } & \multicolumn{1}{|c|}{ O u tp u t } \\
\hline 1 & $\begin{array}{l}\text { Dakwah } \\
\text { Penerangan }\end{array}$ & $\begin{array}{l}\text { Meningkatnya dukungan manajemen } \\
\text { administrasi penerangan agama Islam }\end{array}$ \\
\hline 2 & $\begin{array}{l}\text { Dakwah } \\
\text { Penyuluhan }\end{array}$ & $\begin{array}{l}\text { Meningkatnya kualitas penyuluhan agama } \\
\text { Islam }\end{array}$ \\
\hline
\end{tabular}

Program dan Kegiatan Strategis Bimas Islam di bidang Pengelolaan dan Pembinaan Kualitas Penerangan Agama Islam, khususnya hal yang terkait dengan Penerangan dan Penyuluhan Agama Islam cukup gamblang pada tabel 1. Program apa yang dicanangkan dengan output yang diharapakan untuk vapaya pengelolaan dan pembinaan

\footnotetext{
${ }^{61}$ Diolah berdasarkan Renstra Bimas Islam, 2010-2014, hlm 35-36.
} 
kualitas Penerangan Agama Islam, belum sepenuhnya sinkron dan tidak saling mendukung. Oleh karena output dari program pengelolan tersebut belum proporsional. Output di ranah dakwah penerangan, baru pada upaya "Meningkatnya dukungan manajemen administrasi penerangan agama Islam" dan belum menyentuh pada pengembangan materi serta metode penerangan agama Islam itu sendiri. Sementara output di ranah dakwah penyuluhan, sudah mulai namapak, yaitu "Meningkatnya kualitas penyuluhan agama Islam", yang hal ini harus diformulasikan secara rinci bagaimana materi dan terutama metode penyuluhan dikembangkan.

Dakwahpenerangandandakwah penyuluhansebagaisatukesatuan, maka Dirjen Bimas Islam sudah waktunya mulai mencanangkan bagaimana stratgi dakwah yang memadukan dakwah penerangan dan dakwah penyuluhan dirancang secara serius dan rinci guna mencapai Visi Kementerian Agama, yaitu "Terwujudnya masyarakat Indonesia yang taat beragama, rukun, cerdas, mandiri dan sejahtera lahir batin." Sebagai contoh, kalau program Keluarga Berencana BKKBN pada tahun 1970-an banyak dipermasalahkan hampir semua pihak termasuk para ulama, namun dalam waktu 25 tahun program tersbut mampu mencapai targetnya, yaitu pengurangan kelahiran penduduk dan menjadikan himbauan "punya anak dua cukup" dalam waktu 25 tahun telah dapat berjalan sukses mencapai target dan telah melembaga di hati penduduk Indonesia.

Berbeda dengan progran-program yang dikembangkan di tingkat Kanwil Kemenag Provinsi dan Kantor Kemenag Kabupaten/ Kota, program-programnya sudah mulai mengarah ke visi-misi yang dicanangkan. Sebagai contoh program kegiatan di Kanwil Kemenag Daerah Istimewa Yogyakarta Bidang Penazawa Porsi dakwah penerangan dan dakwah penyuluhan sudah nampak terarah dan seimbang. Pengembangan program dakwah penerangan dan dakwah penyuluhan terlihat beda nyata, terarah dan proporsional, baik dari kegiatan, satuan ukur, jenis keluaran, volume capaian, penerima 
manfaat, metode pelaksanaan dan yang lain. Sudah barang tentu merancang program yang komprehensip, efisien dan efektif tidak bisa instant tetapi membuthkan proses panjang.

\section{Kesimpulan}

Berdasarkan hasil penelitian yang telah dijelaskan di atas, dapat disimpulkan bahwa struktur kelembagaan dakwah yang ada di bawah Kementerian Agama belum linear dengan bidang-bidang kegiatan dakwah. Oleh karena itu, perlu segera diadakan penataan kembali konsep dan nama-nama struktur yang belum konsisten dan berubahubah sehingga menjadi sama dan linier. Dengan penyamaan nama dan linieritas konsep dakwah dalam struktur organisai, program yang dicanangkan menjadi lebih terarah dan lancar. Di samping itu, program dakwahnya juga perlu melakukan beberapa hal, yaitu:

1. Merancang program dakwah yang proporsional antara dakwah penerangan dan dakwah penyuluhan guna merancang dakwah yang komprehensip sehingga dakwah yang dilakukan menjadi lebih komunikatif, efisien dan efektif.

2. Merancang program pengembangan materi dakwah yang strategis dan tetap ditunjang dengan pengembangan program managemen dakwah yang lebih ketat dan terukur.

3. Merancang strategi dakwah yang komprehensif untuk jangka panjang dengan tetap mengembangkan program dakwah yang bersifat solutif, mengatasi masalah yang mucul di mayarakat. 


\section{Daftar Pustaka}

Aziz, Moh. Ali, Ilmu Dakwah, Edisi Revisi (Jakarta: Kencana Prenada Group, 2009)

Anyaegbunam, C., P. Mefalopulos dan T. Moetsabi, Participatory Rural Communication Appraisal, Starting with The People A Handbook, Second Edition (Rome: FAO, 2004)

Dirjen Bimas Islam Kemenag RI. Rencana Strategik Bimbingan Masyarakat Islam (Jakarta, 2010-2014)

Jahi, Amri, "Media Siaran dalam Pembangunn Pedesaan di Negaranegara Dunia Ketiga", dalam Amri Jahi (ed.), Komunikasi Massa dan Pembangunan Pedesaan di Negara-negara Dunia Ketiga (Jakarta: Gramedia Pustaka Utama, 1993)

Kholili, HM., Syamsul Hadi dan Subejo, Islam yang Rahmat dalam Membangun Umat, dalam Jumal Kawistara, Vol. 4, No. 3 Desember (Yogyakarta: SPS UGM, 2015)

Kholili, HM, "Dakwah Penyuluh Agama Islam Fungsional (PAIF) Bimas Islam dalam Membangun Umat di Kabupaten Sleman". Disertasi (Yogyakarta: Universitas Gajah Mada, 2015)

Mardikanto, Totok, Penyuluhan Pembangunan Pertanian (Surakarta: Sebelas Maret Univercity Press, 1993)

Nazir, Moh, Metode Penelitian (Jakarta: Ghalia Indonsia, 1985)

PMA No. 13 Th. 2012 tentang Organisasi dan Tata Kerja Instansi Vertikal Kementerian Agama

Qahthani, al-, Said bin Ali, Dakwah Islam Dakwah Bijak, ter. Masykur Hakim (Jakarta: Gema Insani Press, 1994)

Ratna, N. K, Metodologi Penelitian, Kajian Budaya dan Ilmu Sosial Humaniora pada Umumnya (Yogyakarta: Pustaka Pelajar, 2010) 
Tasâmuh Volume 15, No. 1, Desember 2017

Subejo, Bahan Kuliah Dasar-dasar Penyuluhan dan Komunikasi Pertanian (Yogyakarta: Fakultas Pertanian UGM, 2012)

Zulfikar, Erik, unixlifes. blogspot.com/2011/10/ilmu-penerangan.html (12-1-2013) 